\title{
Article \\ Introgression of the Powdery Mildew Resistance Genes Pm60 and Pm60b from Triticum urartu to Common Wheat Using Durum as a 'Bridge'
}

\author{
Qiang Zhang ${ }^{1,+}$, Yinghui Li ${ }^{2,3, *,+} \mathbb{D}$, Yiwen Li $^{2}\left(\mathbb{D}\right.$, Tzion Fahima ${ }^{3}$, Qianhua Shen ${ }^{2,4, *}$ and Chaojie Xie ${ }^{1, *(\mathbb{D})}$ \\ 1 State Key Laboratory for Agrobiotechnology, Key Laboratory of Crop Heterosis and Utilization (MOE), \\ Key Laboratory of Crop Genetic Improvement, College of Agronomy and Biotechnology, China Agricultural \\ University, Beijing 100193, China; zhang2021qiang2021@163.com \\ 2 State Key Laboratory of Plant Cell and Chromosome Engineering, Institute of Genetics and Developmental \\ Biology, Innovation Academy for Seed Design, Chinese Academy of Sciences, Beijing 100101, China; \\ ywli@genetics.ac.cn \\ 3 Institute of Evolution, University of Haifa, Mt. Carmel, Haifa 3498838, Israel; tfahima@univ.haifa.ac.il \\ 4 CAS Center for Excellence in Biotic Interactions, University of Chinese Academy of Sciences, \\ Beijing 100049, China \\ * Correspondence: liyinghui@evo.haifa.ac.il (Y.L.); qhshen@genetics.ac.cn (Q.S.); \\ xiecj127@126.com (C.X.); Tel.: +86-010-62731064 (Q.S.) \\ + These authors contributed equally to this work.
}

check for updates

Citation: Zhang, Q.; Li, Y.; Li, Y.;

Fahima, T.; Shen, Q.; Xie, C. Introgression of the Powdery Mildew Resistance Genes Pm60 and Pm60b from Triticum urartu to Common Wheat Using Durum as a 'Bridge'. Pathogens 2022, 11, 25. https:// doi.org/10.3390/pathogens11010025

Academic Editor: Lawrence S. Young

Received: 2 December 2021

Accepted: 24 December 2021

Published: 26 December 2021

Publisher's Note: MDPI stays neutral with regard to jurisdictional claims in published maps and institutional affiliations.

Copyright: (c) 2021 by the authors Licensee MDPI, Basel, Switzerland. This article is an open access article distributed under the terms and conditions of the Creative Commons Attribution (CC BY) license (https:/ / creativecommons.org/licenses/by/ $4.0 /)$.

\begin{abstract}
Powdery mildew, caused by the fungus Blumeria graminis f. sp. tritici (Bgt), has limited wheat yields in many major wheat-production areas across the world. Introducing resistance genes from wild relatives into cultivated wheat can enrich the genetic resources for disease resistance breeding. The powdery mildew resistance gene Pm60 was first identified in diploid wild wheat Triticum urartu (T. urartu). In this study, we used durum as a 'bridge' approach to transfer Pm60 and Pm60b into hexaploid common wheat. Synthetic hexaploid wheat (SHW, $\mathrm{AABBA}^{\mathrm{u}} \mathrm{A}^{\mathrm{u}}$ ), developed by crossing $T$. urartu $\left(\mathrm{A}^{\mathrm{u}} \mathrm{A}^{\mathrm{u}}\right)$ with durum $(\mathrm{AABB})$, was used for crossing and backcrossing with common wheat. The Pm60 alleles were tracked by molecular markers and the resistance to powdery mildew. From $\mathrm{BC}_{1} \mathrm{~F}_{1}$ backcross populations, eight recombinant types were identified based on five Pm60-flanking markers, which indicated different sizes of the introgressed chromosome segments from T. urartu. Moreover, we have selected two resistance-harboring introgression lines with high self-fertility, which could be easily used in wheat breeding system. Our results showed that the durum was an excellent 'bridge' for introducing the target gene from diploid T. urartu into the hexaploid cultivated wheat. Moreover, these introgression lines could be deployed in wheat resistance breeding programs, together with the assistance of the molecular markers for Pm60 alleles.
\end{abstract}

Keywords: wheat powdery mildew; Triticum urartu; Pm60; recombinant types; durum as a bridge; introgression lines

\section{Introduction}

Blumeria graminis f. sp. tritici (Bgt) is the disease-causing fungus of wheat powdery mildew, which is one of the most destructive diseases in many major wheat production areas. The disease could be well controlled by genetic resistance in the host; however, throughout history, the pathogen has overcome widely deployed host resistance genes rather rapidly [1]. Until now, more than 80 designated powdery mildew resistance genes $(\mathrm{Pm})$ have been identified in wheat [2]. A significant number of these genes are derived from wild relatives of common wheat, which have chromosomes homologous to that of common wheat. For example, PmG16, Pm41, and MlNFS10 are derived from Triticum turgidum L. var. dicoccoides [3-5], Pm13 and Pm66 from Aegilops longissima [6,7], Pm12 and Pm53 from Ae. speltoides [8,9], Pm21 from Dasypyrum villosum [10], Pm60 from T. urartu [11], and $P m 8$ from Secale cereale [12]. 
The wild diploid wheat, T. urartu $\left(2 \mathrm{n}=2 \mathrm{x}=14\right.$; genome $\left.\mathrm{A}^{\mathrm{u}} \mathrm{A}^{\mathrm{u}}\right)$, is the A-genome donor of tetraploid wheat $T$. turgidum subsp. durum $(2 \mathrm{n}=4 \mathrm{x}=28$; genome AABB) and hexaploid common wheat $T$. aestivum $(2 \mathrm{n}=6 \mathrm{x}=42$; genome AABBDD) [13]. T. urartu has extensive genetic diversity for many traits, including disease resistance and phenological and morphological characteristics [14]. The natural populations of T. urartu are extremely diverse, with adaptive traits that have accumulated over evolutionary time, which allow them to grow under a wide range of environmental conditions [15]. Some T. urartu materials have good resistance to wheat diseases, including powdery mildew, stripe rust, and stem rust [16-18], which makes T. urartu a genetic resource for wheat improvement to enrich the gene pool of wheat [19]. Because of its homology to the A subgenome of durum wheat and common wheat, genes with superior traits in T. urartu can be transferred to tetraploid and hexaploid cultivated wheat through direct hybridization and gene introgression [20,21].

Wide crossing has been an important approach for crop improvement, in which segments containing favorable genes from wild relatives can be introduced into existing crop species through chromosomal recombination [22]. However, the rate of success is very low when directly crossing T. urartu or other wild wheat relatives with hexaploid wheat [23]. In some cases, the use of durum as a 'bridge' approach could be helpful in transferring the genes from wild wheat into common wheat [24]. There are many examples of the utilizations of this approach for the introgression of wild-wheat-derived resistance genes into common wheat (e.g., Sr60, Yr15, Yr36, and PmG16 [3,24,25]; reviewed by Klymiuk [24]). T. urartu is the donor of the A genome of T. durum, and durum shares the same A and B genomes with T. aestivum. Therefore, durum wheat might be suitable also as a 'bridge' between T. urartu and common wheat for the introduction of exogenous genes.

To date, only one powdery mildew resistance gene, $P m 60$, has been cloned from $T$. urartu [11]. Pm60 encodes a protein with a nucleotide-binding site (NBS) and leucine-rich repeat (LRR) domain. Three functional resistance alleles were identified on the Pm60 locus (Pm60, Pm60a, and Pm60b), distinguishable by an 80 amino acid deletion (Pm60a) or insertion $(P m 60 b)$ in the LRR region as compared with Pm60 [11].

In this study, we introgressed Pm60 and Pm60b from T. urartu into common wheat using the durum wheat line Mo75 as a 'bridge'. During the introduction, Pm60 and Pm60b alleles were selected in the progenies via functional molecular markers, and verified according to the resistance phenotype to powdery mildew. Based on graphical genotype analysis, eight different recombinant introgression types were identified that carry different lengths of chromosome segments derived from T. urartu with one of the Pm60 alternative alleles. At the same time, we selected two resistant lines with high self-fertility. These resistant introgression lines provide excellent materials for future wheat powdery mildew resistance breeding.

\section{Materials and Methods}

\subsection{Plant Material}

T. urartu accessions CITR17664 (Baal Bek-Bashari, Lebanon, Pm60), PI428215 (Mardin, Turkey, Pm60b) and PI428315 (Baal Bek-Bashari, Lebanon, Pm60b) carrying the powdery mildew resistance genes $P m 60$ and $P m 60 b$ were used as the Pm60 donor lines [26]. The durum wheat line Mo75, with high susceptibility to Bgt isolate E09, was used as a bridge for the introgression of Pm60 alleles into common wheat (Figure 1). Common wheat lines Fielder, Xuezao, and Shiluan 02-1, which are susceptible to Bgt isolate E09, were used as recurrent parents. 


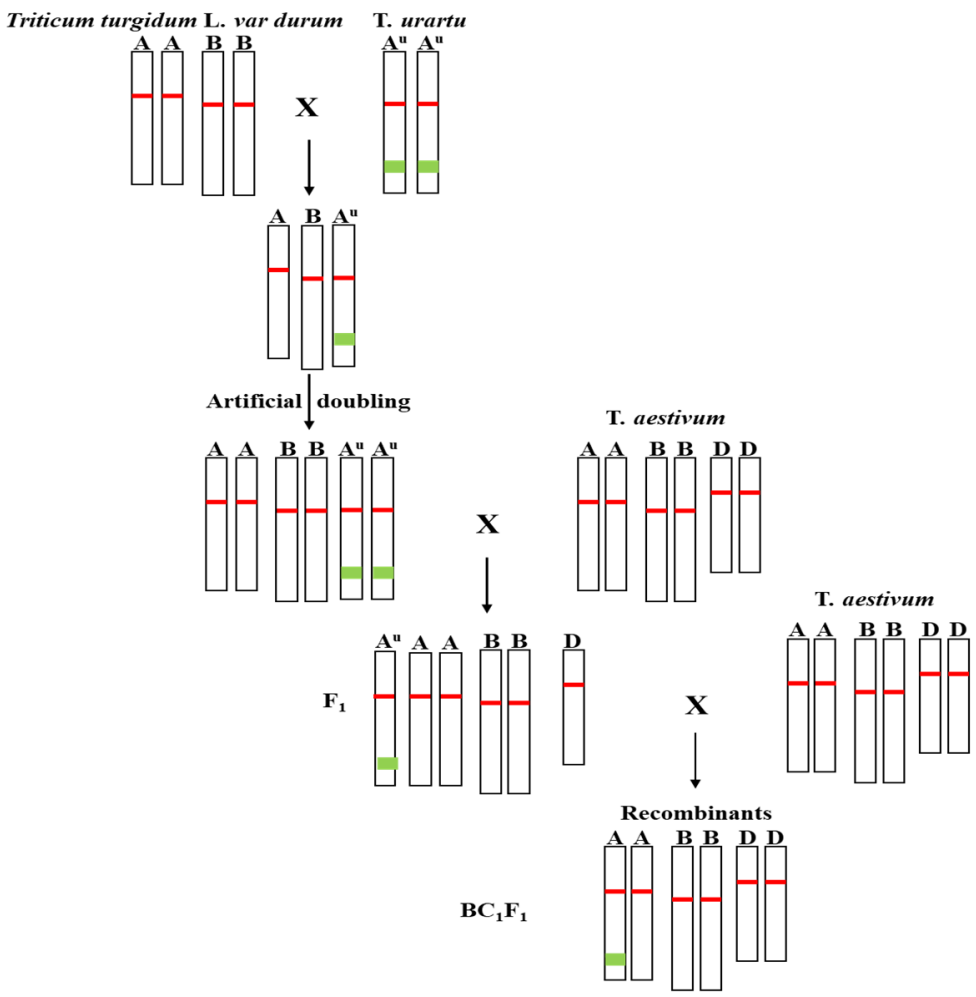

Figure 1. Workflow for the introduction of Pm60 and Pm60b of chromosome 7A from T. urautu into common wheat. The green rectangle on the chromosome represents the Pm60 or Pm60b region and the red rectangular box represents the centromere.

\subsection{Introgression of Disease Resistance Genes}

To introduce the Pm60 and Pm60b from T. urartu into common wheat, a hybridization strategy was devised (Figure 1). The susceptible durum wheat line Mo75 was used as the female to cross with the T. urartu accessions containing Pm60 and Pm60b, and the $\mathrm{F}_{1}$ seeds were harvested. The hybrid seeds were planted in a greenhouse and grown to young plants $\left(\mathrm{ABA}^{\mathrm{u}}\right)$. These plants were removed from the soil at the five- or six-leaf stage for artificial chromosome doubling $\left(\mathrm{AABBA}^{\mathrm{u}} \mathrm{A}^{\mathrm{u}}\right)$. After the soil was gently washed off the roots, the plants were submerged in a mixture of $2.5 \mathrm{mM}$ colchicine $(0.1 \%, w / v)$ and $2 \%$ dimethyl sulfoxide (DMSO) and kept in darkness for $24 \mathrm{~h}$ at $7{ }^{\circ} \mathrm{C}-10{ }^{\circ} \mathrm{C}$ in the growth chamber [27]. After treatment, all plants were thoroughly washed and transplanted in the greenhouse to achieve chromosome doubling (capable of self-crossing), thus creating synthetic hexaploid wheat with the genome of $A A B B A^{u} A^{u}$. The succeeded synthetic hexaploid wheat (SHW) plants could be self-fertile, or were otherwise sterile. The SHW plants were used as the parent to cross with the susceptible common wheat line Xuezao, and the hybrid progeny were evaluated for powdery mildew resistance in the greenhouse. To introduce the powdery mildew resistance genes into more common wheat backgrounds, the resistant hybrid plants were used to cross and backcross with several susceptible wheat lines Fielder, Xuezao, and Shiluan 02-1 in the next crossing process.

\subsection{Bgt Inoculation and Disease Assessment}

The $B g t$ isolate E09, a prevailing pathotype in the Beijing area, is virulent to the resistance genes Pm1a, Pm3a, Pm3c, Pm5a, Pm7, Pm8, Pm17, and Pm19 [28], and was used in this study. The experimental material was cultivated in a growth chamber with a relative humidity of $75 \%$, a diurnal temperature of $26^{\circ} \mathrm{C} / 20^{\circ} \mathrm{C}$, a photoperiod of $14 / 10 \mathrm{~h}$ (light/dark), and a light intensity of $3000 \mathrm{~lx}$. The Bgt isolate E09 was maintained on the susceptible wheat line Xuezao by transferring spores to new plants each week. Inoculations were performed by dusting or brushing conidia from neighboring sporulating susceptible seedlings onto 
the two-week-old wheat seedlings. Approximately 10-14 days after inoculation, when susceptible control plants were fully infected, the infection types (IT) of the tested plants were scored using the $0-4$ scale, where 0 indicated immune with no visible symptoms, 0 ; for necrotic flecks we noted a hypersensitive response (HR), 1 for necrosis with little sporulation, 2 for necrosis with moderate sporulation, 3 for moderate-to-high sporulation without necrosis, and 4 for full sporulation without necrosis [29]. ITs 0-2 were considered resistant and ITs 3-4 were susceptible.

\subsection{Tracing of Pm60 Allele by Molecular Markers}

Total genomic DNA was extracted from young seedling leaves by means of the cetyltrimethylammonium bromide (CTAB) method [30]. DNA samples were quantified using a NanoDrop One spectrophotometer instrument (Nanodrop Technologies, Wilmington, DE, USA) and diluted to a concentration of $30 \mathrm{ng} / \mu \mathrm{L}$.

The Pm60 alleles were tested via amplification with $M-P m 60$ primers [11]. The flanking markers of Pm60 used in the experiments were all from Zou et al. [11] (Table 1). Polymerase chain reaction (PCR) amplification was performed in a $20 \mu \mathrm{L}$ reaction volume, containing $10 \mu \mathrm{L}$ of $2 \times$ Taq PCR StarMix (Genstar, Beijing, China) and loading dye, $4 \mu \mathrm{L}$ of $30 \mathrm{ng} / \mathrm{mL}$ DNA, $2 \mu \mathrm{L}$ of primers (mixture of forward and reverse primers, $2 \mathrm{mM}$ ), and $4 \mu \mathrm{L}$ of $\mathrm{ddH}_{2} \mathrm{O}$. PCR amplification was performed using the marker M-Pm60 with a protocol of 5 min at $94{ }^{\circ} \mathrm{C}$; $35 \mathrm{~s}$ at $94{ }^{\circ} \mathrm{C}, 35 \mathrm{~s}$ at $55^{\circ} \mathrm{C}, 1 \mathrm{~min} 40 \mathrm{~s}$ at $72{ }^{\circ} \mathrm{C}$, and termination after $10 \mathrm{~min}$ of extension at $72{ }^{\circ} \mathrm{C}$ for a total of 35 cycles. For the flanking markers, the primer extension time was $30 \mathrm{~s}$ at $72{ }^{\circ} \mathrm{C}$ and the other PCR conditions were the same as those described above. PCR products were separated in $1 \%$ agarose gels or via $10 \%$ non-denaturing polyacrylamide gel electrophoresis (acrylamide: bisacrylamide $=39: 1$ ), and gels were visualized with silver nitrate staining [31].

Table 1. The PCR primer sequences used in this study.

\begin{tabular}{ccc}
\hline Marker & Primer Sequence $\left(\mathbf{5}^{\prime}-\mathbf{3}^{\prime} \mathbf{)}\right.$ & Purpose \\
\hline$M-P m 60 \mathrm{~F}$ & CATTAACTTTGAGTTGTTGGA & Screening of the Pm60 alleles \\
$M-P m 60 R$ & CGGTGATCATACCAGAATTC & \\
scaf15-5.24 F & CATCATCACAAAGATACCGAT & Linkage marker with Pm60 alleles \\
scaf15-5.24 $R$ & TCGTCTTTATCTCTGCTCCT & \\
scaf22-5.13 F & AATGTAGATCGTCTCTTCGC & Linkage marker with Pm60 alleles \\
scaf22-5.13 $R$ & ACACCTTGTGTTTTGCTCT & \\
scaf7-3.3 F & CGGTTCCATCTCACATTTTG & Linkage marker with Pm60 alleles \\
scaf7-3.3 $R$ & ATTGAGAGTTCGGGATTTGG & \\
scaf5-4.12 F & AGATGAAATTGAGCGAAGTT & Linkage marker with Pm60 alleles \\
scaf5-4.12 $R$ & ATAATCAATGTCCACCGAAG & \\
scaf32-5.24 F & CCACCTCATGAACAACTACC & Linkage marker with Pm60 alleles \\
scaf32-5.24 $R$ & AGGAAACACAACACAACAGG & \\
\hline Note: Detailed information on these markers can be found in a previous report [26].
\end{tabular}

Note: Detailed information on these markers can be found in a previous report [26].

\subsection{Analysis of the Introgressed Fragments Flanking Pm60 Locus}

Analysis of the introgression fragments flanking Pm60 locus in terms of the number and classes of genes and proteins was performed using annotated information of T. urartu (G1812, Tu2.0) and Chinese Spring (RefSeq 1.1) from the Triticeae Multi-omics Center database (http:/ /202.194.139.32/getfasta/index.html) (accessed on 3 March 2021).

\section{Results}

\subsection{Synthesizing Hexaploid $A A B B A^{u} A^{u}$ Wheat by Crossing T. urartu $\left(A^{u} A^{u}\right)$ with Durum $(A A B B)$}

In the previous report, Zhao et al. [26] found that T. urartu accessions CITR 17664 contained Pm60, PI 428215, and PI 428315 contained Pm60b. To introduce Pm60 and Pm60b into common wheat, the susceptible durum wheat line Mo75 was used as a 'bridge'. Firstly, we crossed those three T. urartu accessions (CITR17664, PI428215, PI428315; $\mathrm{A}^{\mathrm{u}} \mathrm{A}^{\mathrm{u}}$ ) with the female parent Mo75 (AABB), and obtained 3-10 $F_{1}$ seeds for each cross. The hybrid 
plants were treated with colchicine for artificial chromosome doubling. Finally, we got 1-3 plants with high self-fertility from each cross, suggesting that the chromosomes in these plants were successfully doubled. Compared with the durum wheat line Mo75, synthetic hexaploid wheat $\left(\mathrm{SHW}, \mathrm{AABBA}^{\mathrm{u}} \mathrm{A}^{\mathrm{u}}\right.$ ) showed some new morphological traits, such as spike brittleness, larger seeds, and longer spikes (Figure 2), which were probably contributed by T. urartu. A powdery mildew test indicated that these SHWs were highly resistant (Table S1; IT = 0-0;) to Bgt isolate E09 at all stages, suggesting that the resistance of Pm60 alleles from diploid T. urartu remained effective and was not suppressed in these hexaploid SHW.

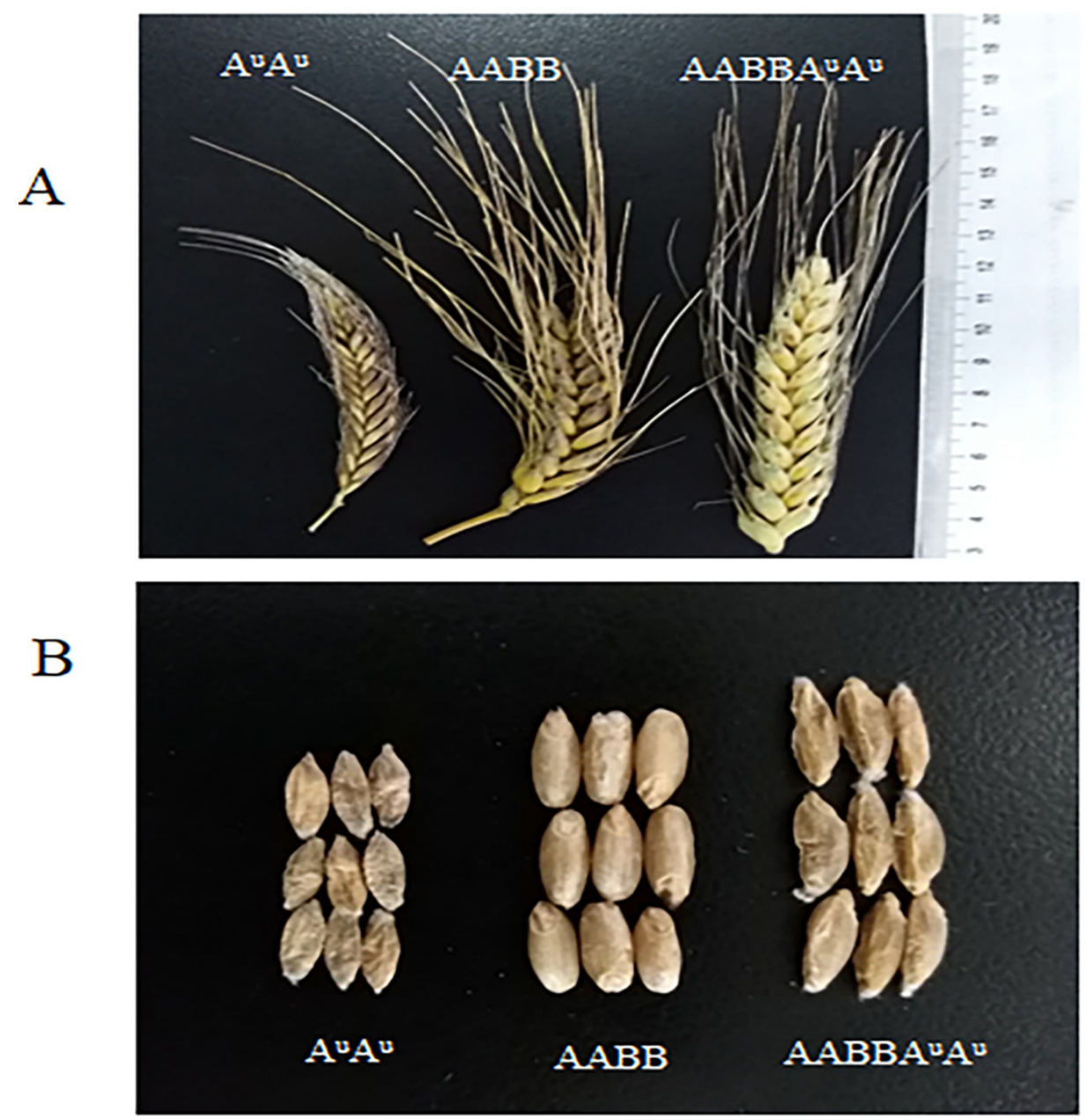

Figure 2. Variation in spike shape (A) and seed size (B) of different ploidy materials. $\mathrm{A}^{\mathrm{u}} \mathrm{A}^{\mathrm{u}}$ is $T$. urartu (PI428215), AABB is Mo75 and $\mathrm{AABBA}^{\mathrm{u}} \mathrm{A}^{\mathrm{u}}$ is the $\mathrm{F}_{1}$ material $(\mathrm{Mo} 75 \times \mathrm{PI} 28215)$ that the chromosome has been doubled by colchicine.

\subsection{Introgression of Pm60 Alleles into Common Wheat}

To introduce Pm60 alleles into the common wheat cultivars, we crossed the SHW accessions with the susceptible common wheat line Xuezao. As expected, all the $\mathrm{F}_{1}$ plants were immune to Bgt isolate E09 (Table 2). Since the $\mathrm{F}_{1}$ plants with a genome of AABBDA ${ }^{\mathrm{u}}$ were sterile, these plants were (back)crossed with several susceptible wheat lines, such as Xuezao, Fielder, and Shiluan $02-1$. We obtained six $\mathrm{BC}_{1} \mathrm{~F}_{1}$ populations using different male parents (Z1, Z2, Z5, Z7, Z10, and Z14, Table 2). After testing the resistance to Bgt isolate E09, we found that four populations (Z1, Z5, Z7 and Z10) met the 1:1 segregation ratio, except for Z2 and Z14 (Table 2). These results indicated that there is one dominant resistance gene segregating (ratio $=1: 1$ ) in these populations. 
Table 2. Segregation of powdery mildew resistance in six backcross populations $\left(\mathrm{BC}_{1} \mathrm{~F}_{1}\right)$.

\begin{tabular}{ccccccc}
\hline \multirow{2}{*}{ No. } & Male (o') & Female (o) & \multicolumn{2}{c}{ Number of Seedlings } & & \\
\cline { 4 - 5 } & & & Resistant & Susceptible & $\chi^{2}$ (1:1) & $p$-Value \\
\hline Z1 & Fielder & $($ Mo75/ PI428215)/Xuezao & 17 & 23 & 0.40 & 0.53 \\
Z2 & Xuezao & (Mo75/ PI428215)/Xuezao & 19 & 9 & 6.3 & 0.01 \\
Z5 & Fielder & (Mo75/ PI428315)/Xuezao & 9 & 13 & 0.18 & 0.67 \\
Z7 & Shiluan 02-1 & (Mo75/ PI428215)/Xuezao & 17 & 15 & 0.51 & 0.48 \\
Z10 & Shiluan 02-1 & (Mo75/ PI428315)/Xuezao & 23 & 21 & 0.37 & 0.54 \\
Z14 & Xuezao & (Mo75/ CITR17664)/Xuezao & 22 & 6 & 29.17 & $0.07 \times 10^{-5}$ \\
\hline Note: Common wheat (AABBDD): Fielder, Xuezao, Shiluan02-1; Durum (AABB): Mo75; T. urartu: PI428215,
\end{tabular}
PI428315, CITR17664.

To verify the presence of $P m 60$ and $P m 60 b$ in these progenies, we adopted the reported marker M-Pm60 (Table 1) [11], a PCR-based functional marker of $P m 60$ that can distinguish between the three alleles (Pm60, Pm60a, and Pm60b) based on the size of the amplification product [11]. Screening of 194 plants of these populations using the marker M-Pm60 confirmed the presence of either the resistance gene Pm60 (PCR product size: $1551 \mathrm{bp}$ ) or the Pm60b allele (PCR product: $1791 \mathrm{bp}$ ) in all the powdery-mildew-resistant plants, which were absent in all of the susceptible plants (Figure 3A,B). Therefore, by combining the phenotyping and genotyping results we were able to confirm that the functional Pm60 alleles were successfully transferred from the diploid T. urartu donor lines into hexaploid wheat introgression lines.

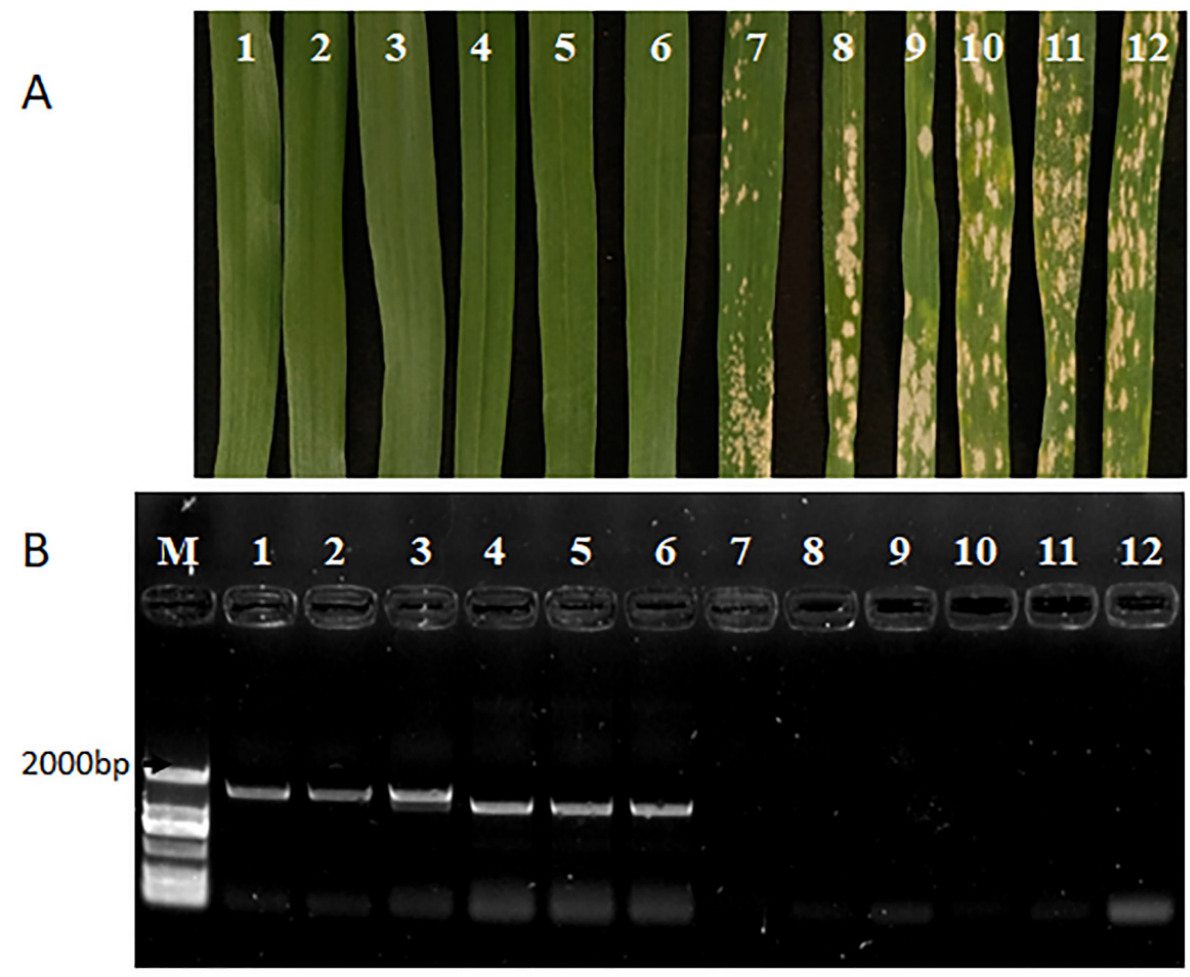

Figure 3. Marker-assisted screening of $P m 60$ and $P m 60 b$ loci and the infection types of different introgression individuals. (A) The infection type (IT) of different introgression individuals at 13 days post-inoculation (1-6: IT = 0, 7-12: IT = 4). (B) Agarose gel electrophoresis of PCR products amplified with marker $M-P m 60$ from 12 progenies; $1-3$ are the resistant introgression individuals (Z1-1, Z5-3, Z10-1) containing Pm60b; 4-6 are the resistant introgression individuals (Z14-1, Z14-2 and Z14-6) containing Pm60; and 7-12 are the susceptible introgression individuals (Z1-2, Z5-1, Z10-2, Z10-3, Z14-4 and Z14-5) without functional Pm60 alleles; M is marker (Direct-load StarMarker D2000 GenStar). 


\subsection{Graphical Genotypes Analysis of the Introgressed Chromosome Segments}

The introgressions of favorable alien genes are often accompanied by the simultaneous transfer of different sizes of chromosomal fragments alongside the target genes [32,33]. Since T. urartu is the A genome donor for common wheat, its chromosomes could freely pair and recombine with the A sub-genome of common wheat. To analyze the sizes of the introgressed chromosome fragments harboring the Pm60 locus in the common wheat genome background, we screened the $\mathrm{BC}_{1} \mathrm{~F}_{1}$ progenies (focusing on the resistant individuals) using the Pm60 flanking markers on the long arm of chromosome 7A (Table S1 and Figure S1). Among these, a total of 16 recombinant events were identified, which could be separated into eight types by the recombination sites based on the genotypes of five Pm60-flanking markers (Figure 4 and Table S1). There were ten recombinants identified in Xuezao, three in the Shiluan 02-1, and three in Fielder. The markers further away from the target gene were more likely to be recombined (Figure 4 and Table S1). Based on the annotation information of the T. urartu material G1812, some introduced chromosome segments were about $18.12-35.59 \mathrm{Mb}$ of the long arm of T. urartu chromosome $7 \mathrm{~A}$ in different recombinants, harboring 411-511 genes (195-328 protein species) from T. urartu (Figure 4). Interestingly, we identified an individual Z1-3 containing double recombination with Pm60b flanking the chromosome segments from Xuezao and Fielder (Figure 4 and Table S1). These results indicated that chromosome 7A of T. urartu was fully homologous to chromosome 7 of common wheat and the size of the introgressive linkage fragments alongside the Pm60 locus could readily be reduced by recombination.

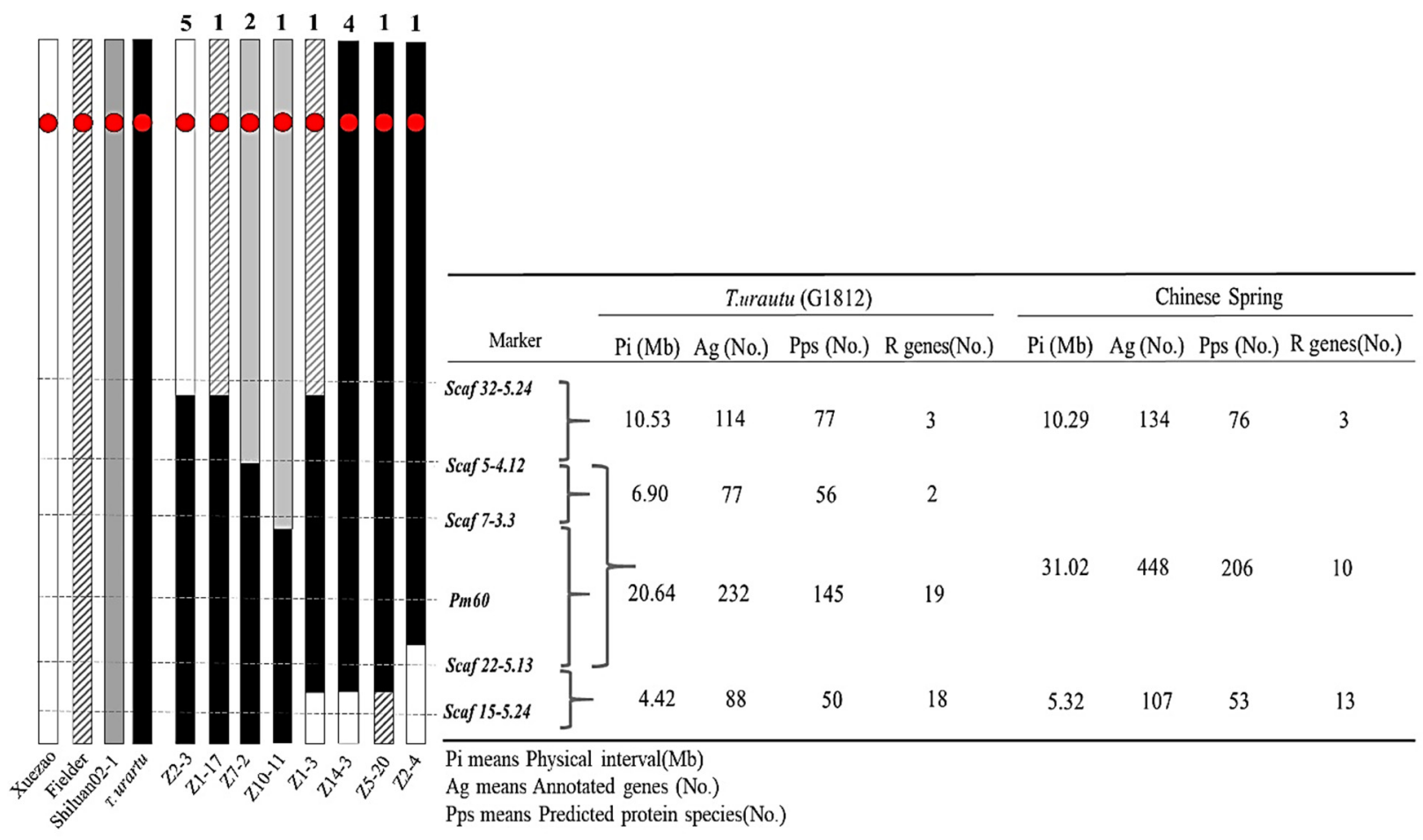

Figure 4. Recombination analysis using five Pm60-flanking markers. Left: Different types of recombinant plants based on marker analysis. The number of the recombinant types (above) and the name of representative introgression lines (below); Red circular boxes represent centromeres; right: physical location of the linked markers on G1812 and Chinese spring, as well as the number of genes annotated and the predicted protein types within the interval.

Among the six $\mathrm{BC}_{1} \mathrm{~F}_{1}$ introgressive populations, we found two recombinant progenies (Z1-4 and Z1-10, which were resistant and contained $P m 60 b$ ) showing high self-fertility with $83.3 \%$ and $84.6 \%$ fertility rates, respectively (Figure 5 ). These two materials can be continuously selected to obtain homozygous resistant lines in the next generations and 
can be used for wheat breeding. However, the other recombinant progenies showed low self-fertility rates which were close to sterile. All of those selected recombinant progenies have been backcrossed with bread wheat and will develop more introgression lines in the future.

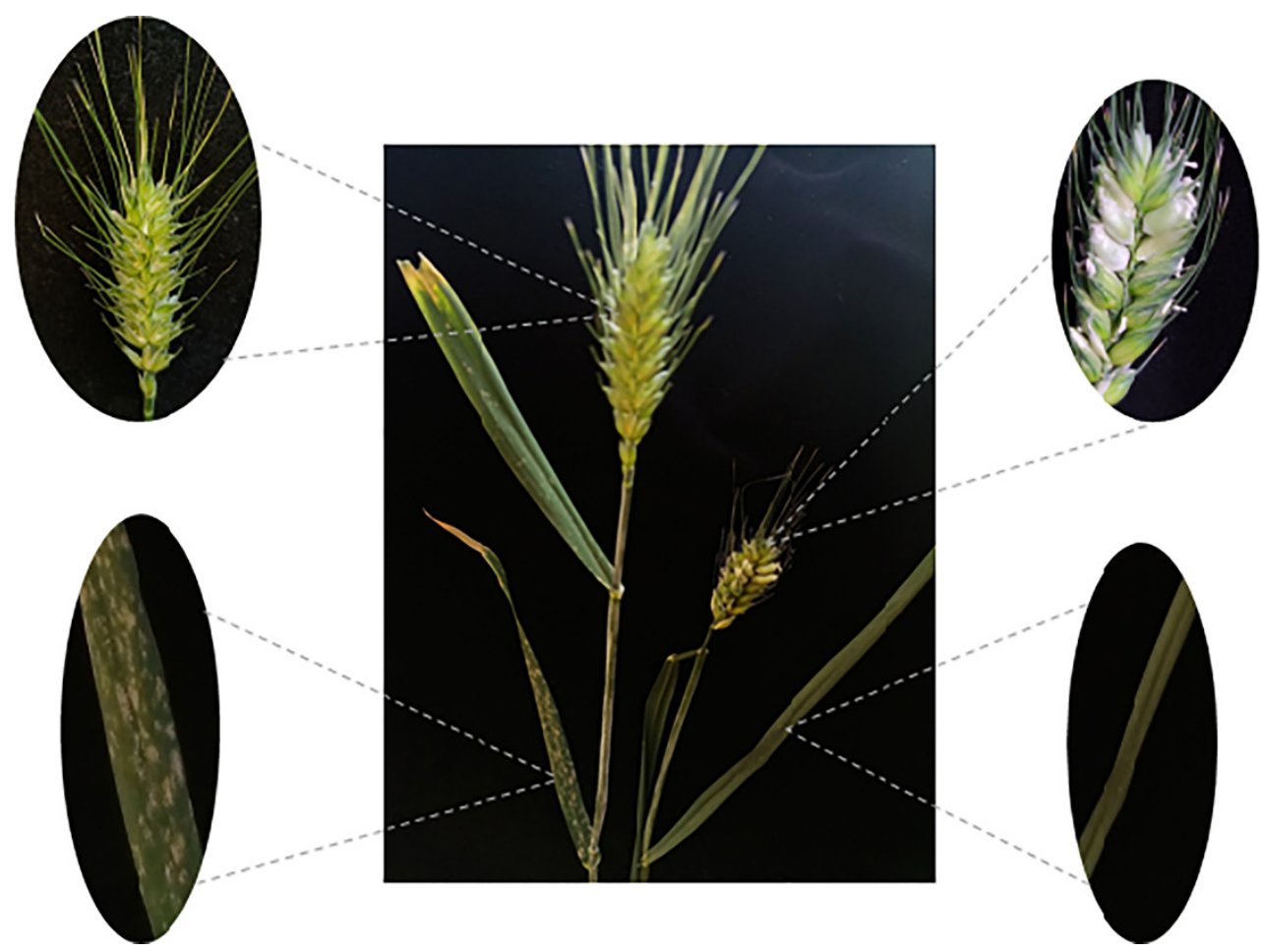

Figure 5. Resistant strains with a high selfing ability. Left: susceptible introgression individual (Z2-1) in the adult stage showing a lower selfing ability. Right: resistant individual (Z2-3) with a higher selfing ability.

\section{Discussion}

The wild relatives of wheat are a tremendous treasure chest of genetic variation for wheat improvement [34]. The incorporation of favorable traits from wild relatives into common wheat is regarded as a valuable way for breeders to increase the genetic diversity of wheat [35]. Molecular markers are now widely used for gene targeting, marker-assisted selection and other genetic studies, allowing tracking of the target gene through different generations of a breeding program, although independently of environmental conditions and growth stage [36]. In this study, the functional marker $M-P m 60$ for Pm60 was applied to test and track Pm60 alleles in the introgression of the target gene, and flanking markers linked to the Pm60 locus were used for the analysis of the size of the introduced fragments (Table 1 and Figure 3B). Taking advantage of those markers, we successfully selected the introgression lines containing Pm60 alleles with different chromosome segments introgressed from T. urartu (Figure 4 and Table S1).

Pm60 alleles have been identified in approximately 34.8\% (67 out of 227) of T. urartu natural populations and approximately $25.2 \%$ (58 out of 230 ) wild emmer wheat accessions $[3,26]$. These results suggest that the Pm60 locus is one of the important Bgt resistance loci in the natural populations of T. urartu and wild emmer wheat. The different Pm60 alleles might be resistant to different $B g t$ isolates. TdPm60 has been transformed from wild emmer wheat into common wheat [3,37]. Since the resistances of Pm60 and Pm60b genes had never been used in common wheat before, in this study, we introduced the Pm60 and Pm60b genes into common wheat and found that their resistances to Bgt E09 were maintained in the hexaploid background (Figure 3A). The obtained introgression lines of Pm60 alleles will enrich the Pm gene pool for wheat breeding. 
Synthetic hexaploid wheats (SHWs) have been successfully used to combine the $\mathrm{AB}$ genome of tetraploid wheat and the $\mathrm{D}$ genome of Ae. tauschii to create synthesized AABBDD wheat [38]. Disease resistance genes of Ae. tauschii have been introduced into common wheat by means of this approach, such as the rust resistance genes $L r 21$ and Sr33 $[39,40]$. In our study, SHWs with the genome of AABBA ${ }^{\mathfrak{u}} \mathrm{A}^{\mathrm{u}}$ were developed through the chromosome doubling of the hybrids of T. durum (AABB) and T. urartu $\left(\mathrm{A}^{\mathrm{u}} \mathrm{A}^{\mathrm{u}}\right)$. Since SHW lines directly combined the whole genome of diploid wild relatives, they showed many undesirable traits, such as late maturity, taller plants, and difficulty in threshing (Figure 2). Therefore, SHWs could be used as a 'bridge' to introduce desirable genes into common wheat to develop superior derivatives (synthetic backcross lines, SBLs) or synthetic derivatives (SYN-DER) with the unfavorable traits eliminated. For example, four SHW derivatives were released during 2003-2005 in Sichuan, China. Among them, Chuanmai 42 has proven to be both a high-yielding variety and an excellent parent, from which 12 varieties have been bred [41]. In this study, we found that the AABBA ${ }^{\mathrm{u}} \mathrm{A}^{\mathrm{u}} \mathrm{SHWs}$ were easy to cross with common wheat and could be used for the introduction of genes from the $\mathrm{A}^{\mathrm{u}}$ genome into common wheat. By crossing SHWs with common wheat and continuously backcrossing with common wheat, we introduced Pm60 alleles into different wheat varieties (Fielder, Xuezao, and Shiluan 02-1) and created highly resistant and fertile derivative lines (Figure 5). However, the SHW also showed unfavorable traits such as spike brittleness and wizened seeds (Figure 1), which could be also induced into the introgression lines during the backcrossing with bread wheat. Therefore, in addition to disease resistance genes, we will also focus on other important agricultural traits such as plant height and yield by using phenotypic and marker-assisted selection in the future backcrossing process.

Supplementary Materials: The following are available online at https://www.mdpi.com/article/10 .3390 / pathogens11010025/s1, Figure S1: The genotypes by the markers which were linked to Pm60 in the introgression lines. Table S1: The phenotypes (to Bgt E09, IT) and genotypes (by 6 markers) of the introgression $\mathrm{BC} 1 \mathrm{~F} 1$ resistant plants.

Author Contributions: C.X., Q.S. and Y.L. (Yinghui Li). designed the research; Q.Z. and Y.L. (Yinghui Li). participated in the writing of the article and the synthesis of the AABBA ${ }^{\mathrm{u}} \mathrm{A}^{\mathrm{u}}$ material; Q.Z. performed the marker analysis and phenotyping for the introgression lines. Y.L. (Yiwen Li) and Q.S. provided the Triticum urartu material. C.X., Q.S. and T.F. reviewed and edited the manuscript. All authors have read and agreed to the published version of the manuscript.

Funding: This work was supported by the National Natural Science Foundation (32171971), the Strategic Priority Research Program of Chinese Academy of Sciences (XDPB16) and Israel Science Foundation, grant number 1719/08 and 1366/18.

Institutional Review Board Statement: Not applicable.

Informed Consent Statement: Not applicable.

Acknowledgments: We thank Xiayu Duan, Institute of Plant Protection, Chinese Academy of Agricultural Sciences, for providing us Bgt isolate E09.

Conflicts of Interest: On behalf of all authors, the corresponding author states that there is no conflict of interest.

\section{References}

1. Golzar, H.; Shankar, M.; D'Antuono, M. Responses of commercial wheat varieties and differential lines to western Australian powdery mildew (Blumeria graminis f. sp. tritici) populations. Australas. Plant Pathol. 2016, 45, 347-355. [CrossRef]

2. Wan, W.; Xiao, J.; Li, M.; Tang, X.; Wen, M.; Cheruiyot, A.K.; Li, Y.; Wang, H.; Wang, X. Fine mapping of wheat powdery mildew resistance gene Pm6 using 2B/2G homoeologous recombinants induced by the ph1b mutant. Theor. Appl. Genet. 2020, 133, 1265-1275. [CrossRef]

3. Li, Y.; Wei, Z.Z.; Fatiukha, A.; Jaiwar, S.; Wang, H.; Hasan, S.; Liu, Z.; Sela, H.; Krugman, T.; Fahima, T. TdPm60 identified in wild emmer wheat is an ortholog of Pm60 and constitutes a strong candidate for PmG16 powdery mildew resistance. Theor. Appl. Genet. 2021, 1-17. [CrossRef] 
4. $\quad$ Li, M.; Dong, L.; Li, B.; Wang, Z.; Xie, J.; Qiu, D.; Li, Y.; Shi, W.; Yang, L.; Wu, Q.; et al. A CNL protein in wild emmer wheat confers powdery mildew resistance. New Phytol. 2020, 228, 1027-1037. [CrossRef]

5. Yin, H.; Fang, X.; Li, P.; Yang, Y.; Hao, Y.; Liang, X.; Bo, C.; Ni, F.; Ma, X.; Du, X.; et al. Genetic mapping of a novel powdery mildew resistance gene in wild emmer wheat from "Evolution Canyon" in Mt. Carmel Israel. Theor. Appl. Genet. 2021, 134, 909-921. [CrossRef] [PubMed]

6. Cenci, A.; D'Ovidio, R.; Tanzarella, O.A.; Ceoloni, C.; Porceddu, E. Identification of molecular markers linked to Pm13, an Aegilops longissima gene conferring resistance to powdery mildew in wheat. Theor. Appl. Genet. 1999, 98, 448-454. [CrossRef]

7. Li, H.; Dong, Z.; Ma, C.; Xia, Q.; Tian, X.; Sehgal, S.; Koo, D.H.; Friebe, B.; Ma, P.; Liu, W. A spontaneous wheat-Aegilops longissima translocation carrying Pm66 confers resistance to powdery mildew. Theor. Appl. Genet. 2020, 133, 1149-1159. [CrossRef] [PubMed]

8. Jia, J.; Devos, K.M.; Chao, S.; Miller, T.E.; Reader, S.M.; Gale, M.D. RFLP-based maps of the homoeologous group-6 chromosomes of wheat and their application in the tagging of Pm12, a powdery mildew resistance gene transferred from Aegilops speltoides to wheat. Theor. Appl. Genet. 1996, 92, 559. [CrossRef]

9. $\quad$ Petersen, S.; Lyerly, J.H.; Worthington, M.L.; Parks, W.R.; Cowger, C.; Marshall, D.S.; Brown-Guedira, G.; Paul Murphy, J. Mapping of powdery mildew resistance gene Pm53 introgressed from Aegilops speltoides into soft red winter wheat. Theor. Appl. Genet. 2015, 128, 303-312. [CrossRef]

10. He, H.; Zhu, S.; Zhao, R.; Jiang, Z.; Ji, Y.; Ji, J.; Qiu, D.; Li, H.; Bie, T. Pm21, encoding a typical CC-NBS-LRR protein, confers broad-spectrum resistance to wheat powdery mildew disease. Mol. Plant 2018, 11, 879-882. [CrossRef]

11. Zou, S.H.; Wang, H.; Li, Y.W.; Kong, Z.S.; Tang, D.Z. The NB LRR gene Pm60 confers powdery mildew resistance in wheat. New Phytol. 2018, 218, 298-309. [CrossRef] [PubMed]

12. McIntosh, R.A.; Zhang, P.; Cowger, C.; Parks, R.; Lagudah, E.S.; Hoxha, S. Rye-derived powdery mildew resistance gene Pm8 in wheat is suppressed by the Pm3 locus. Theor. Appl. Genet. 2011, 123, 359-367. [CrossRef]

13. Brandolini, A.; Hidalgo, A.; Gabriele, S.; Heun, M. Chemical composition of wild and feral diploid wheats and their bearing on domesticated wheats. J. Cereal Sci. 2015, 63, 122-127. [CrossRef]

14. Wang, X.; Luo, G.; Yang, W.; Li, Y.; Sun, J.; Zhan, K.; Liu, D.; Zhang, A. Genetic diversity, population structure and marker-trait associations for agronomic and grain traits in wild diploid wheat Triticum urartu. BMC Plant Biol. 2017, 17, 112. [CrossRef] [PubMed]

15. Brunazzi, A.; Scaglione, D.; Talini, R.F.; Miculan, M.; Magni, F.; Poland, J.; Enrico Pe, M.; Brandolini, A.; Dell'Acqua, M. Molecular diversity and landscape genomics of the crop wild relative Triticum urartu across the Fertile Crescent. Plant J. 2018, 94, 670-684. [CrossRef]

16. Ma, H.; Singh, R.P.; Mujeeb-Kazi, A. Resistance to stripe rust in durum wheats, A-genome diploids, and their amphiploids. Euphytica 1997, 94, 279-286. [CrossRef]

17. Qiu, Y.C.; Zhou, R.H.; Kong, X.Y.; Zhang, S.S.; Jia, J.Z. Microsatellite mapping of a Triticum urartu Tum. Derived powdery mildew resistance gene transferred to common wheat (Triticum aestivum L.). Theor. Appl. Genet. 2005, 111, 1524-1531. [CrossRef] [PubMed]

18. Rouse, M.N.; Jin, Y. Stem rust resistance in A-genome diploid relatives of wheat. Plant Dis. 2011, 95, 941-944. [CrossRef]

19. Grewal, S.; Hubbart-Edwards, S.; Yang, C.; Scholefield, D.; Ashling, S.; Burridge, A.; Wilkinson, P.A.; King, I.P.; King, J. Detection of T. urartu introgressions in wheat and development of a panel of interspecific introgression lines. Front. Plant Sci. 2018, 9, 1565. [CrossRef] [PubMed]

20. Fricano, A.; Brandolini, A.; Rossini, L.; Sourdille, P.; Wunder, J.; Effgen, S.; Hidalgo, A.; Erba, D.; Piffanelli, P.; Salamini, F. Crossability of Triticum urartu and Triticum monococcum wheats, homoeologous recombination, and description of a panel of interspecific introgression lines. G3 Genes Genomes Genet. 2014, 4, 1931-1941. [CrossRef]

21. Gao, F.; Chen, B.; Jiao, J.; Jia, L.; Liu, C. Two novel vesicle-inducing proteins in plastids 1 genes cloned and characterized in Triticum urartu. PLoS ONE 2017, 12, e0170439. [CrossRef] [PubMed]

22. Liu, D.; Zhang, H.; Zhang, L.; Yuan, Z.; Hao, M.; Zheng, Y. Distant hybridization: A tool for interspecific manipulation of chromosomes. In Alien Gene Transfer in Crop Plants; Springer: New York, NY, USA, 2014; Volume 1, pp. 25-42. [CrossRef]

23. Ogbonnaya, F.C.; Abdalla, O.; Mujeeb-Kazi, A.; Kazi, A.G.; Xu, S.S.; Gosman, N.; Tsujimoto, H. Synthetic hexaploids: Harnessing species of the primary gene pool for wheat improvement. Plant Breed. Rev. 2013, 37, 35-122. [CrossRef]

24. Klymiuk, V.; Fatiukha, A.; Huang, L.; Wei, Z.Z.; Kis-Papo, T.; Saranga, Y.; Krugman, T.; Fahima, T. Durum wheat as a bridge between wild emmer wheat genetic resources and bread wheat. In Applications of Genetic and Genomic Research in Cereals, Woodhead Publishing: Sawston, UK, 2019; pp. 201-230. [CrossRef]

25. Chen, S.; Rouse, M.N.; Zhang, W.; Zhang, X.; Guo, Y.; Briggs, J.; Dubcovsky, J. Wheat gene Sr60 encodes a protein with two putative kinase domains that confers resistance to stem rust. New Phytol. 2020, 225, 948-959. [CrossRef] [PubMed]

26. Zhao, F.; Li, Y.; Yang, B.; Yuan, H.; Jin, C.; Zhou, L.; Pei, H.; Zhao, L.; Li, Y.; Zhou, Y.; et al. Powdery mildew disease resistance and marker-assisted screening at the Pm60 locus in wild diploid wheat Triticum urartu. Crop J. 2020, 8, 252-259. [CrossRef]

27. Acanda, Y.; Martínez, Ó.; González, M.V.; Prado, M.J.; Rey, M. Highly efficient in vitro tetraploid plant production via colchicine treatment using embryogenic suspension cultures in grapevine (Vitis vinifera cv. Mencía). Plant Cell Tiss. Org. 2015, 123, 547-555. [CrossRef]

28. Xiao, M.; Song, F.; Jiao, J.; Wang, X.; Xu, H.; Li, H. Identification of the gene Pm47 on chromosome 7BS conferring resistance to powdery mildew in the Chinese wheat landrace Hongyanglazi. Theor. Appl. Genet. 2013, 126, 1397-1403. [CrossRef] 
29. Liu, Z.; Sun, Q.; Ni, Z.; Yang, T.; McIntosh, R.A. Development of SCAR markers linked to the Pm21 gene conferring resistance to powdery mildew in common wheat. Plant Breed. 1999, 118, 215-219. [CrossRef]

30. Saghai Maroof, M.A.; Biyashev, R.M.; Yang, G.P.; Zhang, Q.; Allard, R.W. Extraordinarily polymorphic microsatellite DNA in barley: Species diversity, chromosomal locations, and population dynamics. Proc. Natl. Acad. Sci. USA 1994, 91, 5466-5470. [CrossRef]

31. Bassam, B.J.; Caetano-Anollés, G.; Gresshoff, P.M. Fast and sensitive silver staining of DNA in polyacrylamide gels. Anal. Biochem. 1991, 196, 80-83. [CrossRef]

32. Gao, L.; Koo, D.H.; Juliana, P.; Rife, T.; Singh, D.; da Silva, C.L.; Lux, T.; Dorn, K.M.; Clinesmith, M.; Silva, P.; et al. The Aegilops ventricosa $2 \mathrm{~N} v \mathrm{~S}$ segment in bread wheat: Cytology, genomics and breeding. Theor. Appl. Genet. 2021, 134, 529-542. [CrossRef]

33. Adonina, I.G.; Timonova, E.M.; Salina, E.A. Introgressive Hybridization of Common Wheat: Results and Prospects. Russ. J. Genet. 2021, 57, 390-407. [CrossRef]

34. Huang, L.; Raats, D.; Sela, H.; Klymiuk, V.; Lidzbarsky, G.; Feng, L.; Krugman, T.; Fahima, T. Evolution and adaptation of wild emmer wheat populations to biotic and abiotic stresses. Annu. Rev. Phytopathol. 2016, 54, 279-301. [CrossRef]

35. Jiang, J.; Friebe, B.; Gill, B.S. Recent advances in alien gene transfer in wheat. Euphytica 1993, 73, 199-212. [CrossRef]

36. Younis, A.; Ramzan, F.; Ramzan, Y.; Zulfiqar, F.; Ahsan, M.; Lim, K.B. Molecular markers improve abiotic stress tolerance in crops: A review. Plants 2020, 9, 1374. [CrossRef] [PubMed]

37. Wu, Q.; Zhao, F.; Chen, Y.; Zhang, P.; Zhang, H.; Guo, G.; Xie, J.; Dong, L.; Lu, P.; Li, M.; et al. Bulked segregant CGT-Seqfacilitated map-based cloning of a powdery mildew resistance gene originating from wild emmer wheat (Triticum dicoccoides). Plant Biotechnol. J. 2021, 9, 1288-1290. [CrossRef] [PubMed]

38. Börner, A.; Ogbonnaya, F.C.; Röder, M.S.; Rasheed, A.; Periyannan, S.; Lagudah, E.S. Aegilops tauschii introgressions in wheat. In Alien Introgression in Wheat; Springer: Cham, Switzerland, 2015; pp. 245-271. [CrossRef]

39. Naz, A.A.; Bungartz, A.; Serfling, A.; Kamruzzaman, M.; Schneider, M.; Wulff, B.B.; Pillen, K.; Ballvora, A.; Oerke, E.C.; Ordon, F.; et al. Lr21 diversity unveils footprints of wheat evolution and its new role in broad-spectrum leaf rust resistance. Plant Cell Environ. 2021, 44, 3445-3458. [CrossRef] [PubMed]

40. Periyannan, S.; Moore, J.; Ayliffe, M.; Bansal, U.; Wang, X.; Huang, L.; Deal, K.; Luo, M.; Kong, X.; Bariana, H.; et al. The gene Sr33, an ortholog of barley Mla genes, encodes resistance to wheat stem rust race Ug99. Science 2013, 341, 786-788. [CrossRef]

41. Li, J.; Wan, H.S.; Yang, W.Y. Synthetic hexaploid wheat enhances variation and adaptive evolution of bread wheat in breeding processes. J. Syst. Evol. 2014, 52, 735-742. [CrossRef] 